\title{
Autonomy and Creative Thinking Skills of Prospective Elementary School Teacher Students in Learning Mathematics with Science Phenomena assisted by the Learning Management System
}

\author{
Suprih Widodo \\ School of Post Graduate, Universitas Pendidikan Indonesia, Bandung, Indonesia \\ https://orcid.org/0000-0003-2709-4804 \\ Turmudi \\ School of Post Graduate, Universitas Pendidikan Indonesia, Bandung, Indonesia \\ https://orcid.org/0000-0001-7976-211X \\ Rizki Rosjanuardi \\ School of Post Graduate, Universitas Pendidikan Indonesia, Bandung, Indonesia \\ https://orcid.org/0000-0001-5280-6901
}

\begin{abstract}
This research intends to explain the autonomy and creative thinking skills of prospective elementary school student teachers in mathematics with the learning management system (LMS)-assisted science phenomenon. The data collection was done by using test instruments in the form of essay questions to capture the creative thinking skills and a non-test in the form of a questionnaire was used to capture the autonomy skills of prospective elementary school student teachers. The data were analysed through several stages, namely data reduction, data presentation, data conclusions, and data validation using triangulation. The result of the research shows that using the LMS can improve the creative thinking skills of prospective elementary school teachers, while their autonomy skills in experimental classes and control classes indicate no difference. This happens because students were given the same opportunity to explore the material independently. Thus, a way to develop autonomy through mathematics learning needs to be explored.
\end{abstract}

Keywords: autonomy; creative thinking skills; learning management system; science phenomenon

\section{Introduction}

Principals in Indonesia have indicated that the new graduates of educators have 
low levels of competence (Widodo, 2016b). Teachers with teaching experience also have low levels of pedagogical and professional competencies (Giarti, 2016). In addition to having hard skills, the competence of elementary school teachers must also include soft skills and 21 ${ }^{\text {st }}$ century skills (KA21) which are often referred to as the $4 \mathrm{Cs}$, namely critical thinking, collaboration, communication and creativity that are useful in their personal and professional lives (P21, 2011). In mathematics learning, the Partnership for $21^{\text {st }}$ Century Skills also defines the skills of the $21^{\text {st }}$ century through a $21^{\text {st }}$ century skill mathematics map in the field of learning and innovation skills for $\mathrm{K} 12$ consisting of creativity, critical thinking, communication and collaboration (P21, 2011).

Based on the literary search, not much research in mathematics learning has been done related to the development of $21^{\text {st }}$ century skills. Nevertheless, Salehudin et al. (2015) explained that through mathematics learning educators can provide support for students to master the skills of the $21^{\text {st }}$ century. Mathematics learning research in Indonesia and some countries is still focused on mathematical skills as proposed by the National Council of Teachers of Mathematics (NCTM) (2000a). These skills consist of five process skills that students must master through mathematics learning, namely (i) problem solving (Mushlihuddin \& Nurafifah, 2018; Maslukha et al., 2018; Fuchs et al., 2004); (ii) reasoning and proof (Lestari, 2019; Kramarski \& Mevarech, 2003); (iii) connections (Nabilah, 2019; Fauzi, 2015); (iv) communication (Fauzi \& Priatna, 2019; Brendefur \& Frykholm, 2000; Buchholz, 2005) and (v) representation (Effendi, 2012).

Two research studies in mathematics learning related to $21^{\text {st }}$ century skills have been conducted by Turmudi et al. (2017) and Afifah (2019). In the research by Turmudi et al. (2017), they applied mathematics learning with didactic science to develop $21^{\text {st }}$ century skills consisting of critical thinking skills, creativity, communication and collaboration. Afifah (2019), on the other hand, developed the $21^{\text {st }}$ century skills of grade VIII students in mathematics learning with projectbased learning. Another $21^{\text {st }}$ century skills development was carried out by Muhajir (2018) who trained 21 ${ }^{\text {st }}$ century skills in physics learning and other experiments in Malaysia by testing several $21^{\text {st }}$ century skills in the fourth grade (Salehudin et al., 2015).

This research will discuss the development of creative thinking skills as one aspect of the $21^{\text {st }}$ century skills. Creative thinking skills are related to the skill of discovering new things that have not existed before and are original, developing new solutions to each problem, and involving the ability to generate new, varied, and unique ideas (Chiam, 2014).

Mathematics as an important knowledge mastered by students can also contribute to the development of $21^{\text {st }}$ century skills. However, in reality, many consider mathematics to be an area of knowledge that is often regarded as a difficult and intimidating lesson for students (Ashcrafts, 2002; Siregar, 2017). This is caused by 10 factors (Widodo, 2016a), among which is the fact that "there are not many mathematics books published in Indonesia that present problems in the form of context, as a result, mathematics feels abstract and difficult to learn". He 
also explained that mathematics is considered difficult because of the perception of the student him- or herself who considers mathematics as a difficult lesson. Many parents impart to their children the notion that mathematics is difficult so that from childhood until adulthood, they have the perception that mathematics is difficult and intimidating.

This relates to self-regulation, anxiety levels and student pressures studied in relation to psychological well-being. The concept of psychological well-being was originally introduced by Bernice Neugarten in 1961. She stated that psychological well-being is a psychological condition at a time when a person reaches old age (Tobin \& Neugarten, 1961). The two main approaches to understanding psychological well-being, according to Ryff (2013), are, firstly, the focus on happiness in the sense of achieving happiness and preventing pain; and the second approach is the awareness of being an overall functional or whole person, including a healthy body and state of mind (Stern, 2007). Research on the well being of children has been conducted in several parts of the world. In the United Kingdom (UK), child welfare was researched (Rees et al., 2010) while in the United States (US), the well-being of children was the topic of research (Huebner \& McCullough, 2010). This was also the case in Indonesia (Muqodas, 2019); however, mathematics education was not included.

Taking into consideration the background above and the Covid-19 pandemic, this research adopted a $21^{\text {st }}$ century learning approach. There are nine principles

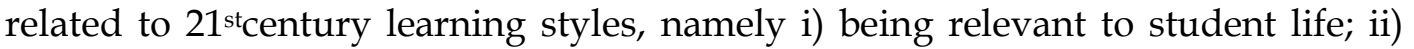
applying cross-disciplinary learning; iii) developing critical thinking skills; iv) encouraging the transfer of knowledge; v) teaching students how to learn; vi) conveying misunderstandings directly; vii) collaborating; viii) exploiting technology to support learning and ix) developing student creativity (Savedra \& Ofter, 2012). As an implementation of the $21^{\text {st }}$ century learning style, this research integrated technology and mathematical learning approaches using scientific phenomena to develop creative thinking skills and autonomy.

In 2000, the National Council of Teachers of Mathematics (NCTM) made recommendations for integrating technology in mathematics learning through technology principles (NCTM, 2000b). The technology principle states that technology is important in mathematics learning and teaching activities since it influences how mathematics is taught and improves student learning activities. Furthermore, the NCTM states that technology can facilitate the process of solving mathematical problems, communication, reasoning and evidence. This is in line with the research of Ayers et al. (1988).

Many research findings conclude that technology is the most suitable instrument to develop mathematics learning and teaching activities. The activity of writing, processing, and studying computer algorithm outputs can improve the understanding of mathematical concepts and principles, numeracy skills, and problem-solving abilities of students (Hatfield \& Kieren, 1972). Technology is the infrastructure used in mathematics education (Kaput et al., 2019). Furthermore, they contend that to realize the technological potential, a new pedagogical method 
is needed, and teacher development needs to be conducted. Kaput et al. (2019) also shared the results of their research on classroom connectivity (CC), namely classes involving technology.

However, the use of technology in learning mathematics is still a rare occurrence. Some people think that learning mathematics using technology is not effective enough to increase the passion for learning. Usually, the technology used in learning mathematics comprises Cabri Geometry (Kösa et al., 2002), Kahoot for quizzes (Göksün \& Gürsoy, 2019; Prieto, 2019), Maple (Blyth \& Labovic, 2009), SPSS to process data (Xiao et al., 2015), calculators (Penglase \& Arnold, 1996) and PhotoMath for proof (Hamadneh \& Al-Masaeed, 2015). However, it is still rare for researchers to consider the use of mathematics learning technology for distance learning.

It needs to be borne in mind that all students globally who are impacted by Covid-19 must learn remotely. Therefore a remote management system called the learning management system (LMS) is necessary. LMS is a management system for distance learning, online learning or e-learning. It enables students to study any time and any where. In an emergency, LMS functions as a distance learning, online learning or e-learning infratstructure By using LMS, teachers and lecturers can monitor student activities through a student attendance management system, provide diverse learning resources (text, video, audio, animation) and connect to other sources on the Internet such as structured assignments and quizzes with interesting forms, as well as enabling discussion forums. Furthermore, LMS can provide tools for collaboration and for both asynchronous learning (teachers and students access the system at different times) and synchronous (teachers and students access the system together and real-time) so that they can converse directly (Widodo, 2017). Studies in the use of LMS in learning have been carried out in universities by Bealty and Ulasewicz (2006), Kelley et al. (2016), McGill and Klobas (2009) and Weaver et al. (2008). However, research reports on the use of LMS in the field of mathematics learning are still rare, considering some of the limitations of the features in LMS that can be used.

The basis of the selection of scientific phenomena in this research is that the nature of mathematics is non-independent knowledge that can help humans in understanding and mastering social, economic and natural problems (Kline, 1973). Mathematics is an emerging science, evolving from real life and serving as a practical tool for real problems (Boyer, 2011). Studies on phenomenon-based learning to improve the cognitive and affective abilities of students through mathematics learning have been conducted related to the development of mathematical abilities of students by Aisah (2015), Faturohman (2015), Hidayat (2015) and Rosyid (2015). The results of these research studies show that phenomenon-based mathematics learning can improve students' mathematical abilities (mathematical communication skills and mathematical connections) and critical thinking. Meanwhile, research that has been trying to develop $21^{\text {st }}$ century skills required by students through mathematics learning has been conducted by Turmudi (2017), who developed the didactic design of mathematics learning through science phenomena and applied it to junior high school students. In 
addition, $21^{\text {st }}$ century skills development has been widely applied to STEM-based integrative mathematics learning by Becker and Park (2011), Bell (2010) and Kim and Park (2012).

\section{Research Problem}

Departing from empirical-conceptual conditions as described above, this research examines the development of autonomy as one of the aspects in psychological well-being and creative thinking skills in mathematics learning with the phenomenon of LMS-assisted science in prospective elementary school teachers.

\section{Conceptual Framework}

Starting with the background, the research problem, and the pandemic of Covid19, a 21st century learning approach was adopted for this study. As an implementation of the $21^{\text {st }}$ century learning style, this research integrates technology and mathematical learning approaches using scientific phenomena to develop creative thinking skill and autonomy. For technology issues, the National Council of Teachers of Mathematics (NCTM) made recommendations for integrating technology in mathematics learning through technology principles (NCTM, 2000b). In terms of scientific phenomena issues, the nature of mathematics as a non-independent knowledge can help humans in understanding and mastering social, economic and natural problems (Kline, 1973). Mathematics is an emerging science, evolving from real life and serving as a practical tool for real problems (Boyer, 2011). Moreover, mathematics explains phenomena and their occurrence via teachers to students (Turmudi, 2014).

\section{Theoretical Framework}

\subsection{Autonomy and Creative Thinking Skill}

Autonomous people are independent people who can determine the best for themselves (Keyes \& Ryff, 1999). These individuals have an internal locus of evaluation, i.e. not seeking the consent of others but rather evaluating themselves by personal standards. Therefore, they do not think about the expectations and judgments of others towards them. Furthermore, autonomous individuals do not rely on the judgment of others to make important decisions. They do not conform to social pressures to think and act in any particular way.

The first dimension of learning and innovation skill for $\mathrm{K} 12$ is creativity. Creativity relates to discovery, trying new approaches to solving problems and being innovative (P21, 2011). In line with the views of Chiam et al. (2014), creativity is explained as a skill for discovering new things that have not existed before, being original, developing new solutions to each problem, and involving the ability to generate new, varied, and unique ideas (Chiam et al., 2014). Creativity is the ability to uncover new relationships, to see things from a new point of view, and to form new combinations of two or more concepts that have been mastered before (Suryadi, 2005).

Based on the explanation above, creative and innovative thinking skills in this research is the ability to generate new ideas that are original and different from others, and to provide many solutions to problems. The indicators used in 
measuring creative thinking skills in this study refer to indicators of creative thinking skills (Torrance, 1966, 1974) known as TTCT and presented in Table 1.

Table 1: Torrance creative thinking skills indicators $(1966,1974)$

\begin{tabular}{|l|l|l|}
\hline 1 & Fluency & Mention many problem-solving solutions \\
\hline 2 & Flexibility & Provide different answers of solutions \\
\hline 3 & Originality & $\begin{array}{l}\text { Create new solutions or answers that have } \\
\text { never been used before to solve problems }\end{array}$ \\
\hline 4 & Elaboration & Mention the complete solutions \\
\hline
\end{tabular}

\subsection{Mathematics Learning with Science Phenomena}

Science phenomenon-based mathematics learning is derived from Freudenthal's didactical phenomenology theory (Freudenthal, 2002). Didactic phenomenonbased mathematics learning in mathematical learning introduces appropriate and suitable phenomena for students in learning mathematical concepts (Freudenthal, 2002; Turmudi, 2014). In this research, the phenomena introduced to students are phenomena related to science. The science phenomenon that is introduced to students is learning that emphasizes the importance of contextual issues to introduce mathematical topics to students.

Phenomenology comes from the Greek phaninomenon meaning 'emerging', and logos meaning 'science' (Turmudi, 2017). The philosophy of phenomenology is learning about consciousness as the experience of the subject (or the view of the first person) (Turmudi, 2017). The term 'phenomenology' is usually followed by the word 'didactic', which means that learning begins with or departs from an experience and consciousness. In mathematics learning, he illustrated that students can be invited to walk on the floor (tiles) then explained to raise awareness that the floor tiles have mathematical value. Then the students pause, try to observe, look deeply, and imagine the mathematical value that can be derived from the experience. Furthermore, students can try to conjecture in the form of questions, then collect data or information to support the notion in order to make abstractions or conclusions (Turmudi, 2017).

\subsection{Learning Management System}

The Learning management system (LMS) is a system or software as an infrastructure in electronic, online or distance learning (McGill \& Klobas, 2009; Watson \& Watson, 2007). The existence of this LMS cannot be separated from the opportunities for learning using Internet technology and networks. The capabilities and features of the LMS depend on the needs of the organization that uses the system to manage learning. Dye and Fagerberg (2004) explain that in general an LMS must have the following capabilities:

1. Registration for administrators, teachers and students on curriculum or learning;

2. Linking curriculum and learning administration to learning content;

3. Supporting traditional virtual learning;

4. Supporting various kinds of analysis and assessment, tracking team or individual progress;

5. Ability to administer test results, assessments and reports; and 
6. Capability management so that an organization can measure learning needs and identify development needs.

LMS is a powerful technology that has yet to reach its full potential and is important for the Information Age paradigm of education (Watson \& Watson, 2007). Because of its importance, greater care and understanding needs to be used when applying the term in research literature. In its implementation, the LMS that used was known as blended learning. Blended learning is a formal education program in which a student learns, at least in part, through online delivery of content and instruction with some element of student control over time, place, path, and pace (Staker \& Horn, 2012). In the blended learning model, students study teaching materials at home, communicating with other students and teachers through online discussions. Concepts can be reinforced by the teacher through student involvement. Therefore, owing to the Covid-19 pandemic, this research study was conducted online.

\section{Methods}

\subsection{Design}

The experimental design to obtain KA21 and PWB data used in this research is the posttest-only design with a nonequivalent control group as presented in Figure 1. In this design, the experimental group and the control group were given a posttest, with the experimental class being given the treatment of mathematical learning with a filtered-s least mean square (FSLMS) algorithm. The preexperiment design used is depicted below:

\begin{tabular}{|l|}
\hline Group $\mathrm{AX}_{1} \rightarrow \mathrm{O}$ \\
\hline Group B $\mathrm{X} \rightarrow \mathrm{O}$ \\
\hline
\end{tabular}

Figure 1: KA21 quantitative pre-experimental research design

Note:

$\mathrm{X}_{1}$ : Treatment to the experimental class

$X:$ Treatment to the control class

$\mathrm{O}:$ Post-test

This design is used to determine how LMS variables affect creative thinking skills in KA21 and autonomy in PWB.

\subsection{Participants}

The population in this study were all the semester 1 students of prospective elementary school teacher level 2 at a university located in two provinces, namely in West Java and Banten. The samples taken to test the model in this research were four (4) classes of diverse students, two classes of which were used as experimental classes, and the remaining two (2) classes were comparison classes. The students in all four classes numbered approximately 156 students. The sampling technique used was a purposive sampling technique. Purposive sampling is a sampling technique based on knowledge of the characteristics of the population and the purpose of the research (Fraenkel, 2012). In the experimental classes from the sample, mathematics learning was carried out using LMS-assisted science phenomena mathematics learning (FSLMS). In this research, mathematics 
learning with science phenomenon was applied to rational number material to the prospective elementary school student teachers level II.

\subsection{Research Instruments}

The instruments used in this research were questionnaires related to the autonomy or independence of learning that has been validated and tested. There were 14 statements which were based on the theory of Ryff (1999) and the development of autonomous instruments (Muqodas, 2019). Tests related to rational numbers of three essay questions were also given to students to test their creative thinking skills. These had been previously validated and empirically tested. The test question refers to indicators 1, 2, 3 of Torrance's creative thinking skills (Torrance, 1966, 1974).

\subsection{Settings}

Learning was conducted in a blended way. At each meeting, lecturers presented learning plans, teaching materials in various forms such as audio, video and presentations as well as discussion materials on the LMS. At the beginning of the lesson, the lecturer initiated the learning synchronously by providing the details, conveyed the learning objectives, scientific phenomena to be studied and quizzes. Then the lecturer gave an explanation related to the activities that would be carried out next, accompanied by a question and answer session. After that, students studied the teaching materials. This was followed by carrying out activities asynchronously. The lecturer guided learning activities through LMS and a WhatsApp group. Once the asynchronous session had been completed, the learning continued with a synchronous discussion. Students delivered practical results in turn, then shared ideas, notions and questions and reflected on the learning that had taken place.

\section{Results and Discussion}

\subsection{Autonomy of Prospective Elementary School Student Teachers}

The descriptive analysis of the autonomy of prospective elementary school teachers students is described in Table 2.

Table 2: Description of PWB-A prospective elementary school teachers

\begin{tabular}{|c|c|c|c|c|c|c|c|}
\hline Description & $A(1)$ & $A(2)$ & Category & $\mathbf{F}(\mathbf{1})$ & $\% \mathbf{f}(\mathbf{1})$ & $f(2)$ & $\% f(2)$ \\
\hline Average Score & 52.17 & 51,48 & Very High & 0 & 0.00 & 0 & 0,00 \\
\hline Highest Score & 71.00 & 71,00 & High & 54 & 62.07 & 39 & 44,83 \\
\hline Lowest Score & 41.00 & 30,00 & Low & 33 & 37.93 & 48 & 55,17 \\
\hline Ideal Score & 84.00 & 84,00 & Very Low & 0 & 0.00 & 0 & 0,00 \\
\hline StDev & 6.26 & 6,92 & Total & 87 & 100.00 & 87 & 100,00 \\
\hline \multicolumn{8}{|c|}{$\begin{array}{l}\text { Information: } \\
\text { A(1): PWB-A results in the FSLMS mathematics learning group } \\
\text { A(2): PWB-A results in the TFSLMS mathematics learning group } \\
\text { F(1) : Frequency of students in each category in the FSLMS mathematics learning group } \\
F(2) \text { : Frequency of students in each category in TFSLMS mathematics learning group }\end{array}$} \\
\hline
\end{tabular}


Based on Table 2, it was found that PWB-A students are prospective elementary teachers in mathematics learning groups with FSLMS and TFSLMS for the following reasons:

1. There was an average score difference of 0.69 where the learning group with FSLMS was higher than the TFSLMS. However, the standard deviation score of the learning group with FSLMS was lower by 0.66 than the mathematics learning group with TFSLMS;

2. The highest score in the mathematics learning group with FSLMS was the same as that of the TFSLMS group; however, the lowest score was 11 points higher than the TFSLMS math learning group. Therefore the range of PWB-A scores in the mathematics learning group with FSLMS was 9 points less than that of the TFSLMS group;

3. After treatment, neither of the learning groups with FSLMS or TFSLMS had students with very high PWB-A scores, or very low scores; and

4. The percentage of prospective elementary school student teachers who have a low PW-A score is higher in the mathematics learning group with TFSLMS.

Based on the PWB-A normality and homogeneity test, it was found that PWB-A data of prospective elementary school student teachers in the mathematics learning groups with FSLMS and TFSLMS are normal and homogeneous. On that basis, the two different tests were conducted on average by using t-test using $=$ 0.05 . The test results are shown in Table 3.

Table 3: Test differences in PWB-A of prospective elementary school student teachers

\begin{tabular}{|l|l|r|r|r|r|r|}
\hline \multirow{2}{*}{ Result } & \multicolumn{6}{|c|}{ t-test for Equality of Means } \\
\cline { 2 - 7 } & \multicolumn{2}{|c|}{$t$} & $d f$ & $\begin{array}{l}\text { Sig. (2- } \\
\text { tailed) }\end{array}$ & Mean Difference & $\begin{array}{l}\text { Std. Error } \\
\text { Difference }\end{array}$ \\
\hline $\begin{array}{l}\text { PWB-A } \\
\text { POSTES }\end{array}$ & $\begin{array}{l}\text { Equal variances } \\
\text { assumed }\end{array}$ & -0.169 & 172 & 0.866 & -0.184 & 1.091 \\
\hline
\end{tabular}

Based on Table 3, t-test results indicate that the sig score. is $0.866>0.05$. Thus $\mathrm{H}_{0}$ is accepted, which means that there is no difference in the average score of PWB-A data of prospective elementary school student teachers in the mathematics learning group with FSLMS and TFSLMS.

\subsection{Creative Thinking Skills (KKf) of Prospective Elementary School Student Teachers}

The description of creative thinking skills of prospective elementary school teacher students is shown in Table 4.

Table 4: Description of KKf achievement of prospective elementary school student teachers

\begin{tabular}{|l|l|l|}
\hline \multirow{2}{*}{ KKf Achievement } & \multicolumn{2}{|c|}{ Class } \\
\cline { 2 - 3 } & FSLMS & TFSLMS \\
\hline Average & 7,58 & 3,67 \\
\hline Highest Score & 12 & 10 \\
\hline Lowest Score & 0 & 0 \\
\hline St Dev & 3,64 & 7,61 \\
\hline Ideal Score & 16 \\
\hline
\end{tabular}


Based on Table 4, the achievement score of KKf of prospective elementary school student teachers in the mathematics learning group with FSLMS and TFSLMS can be explained as follows:

1. There was an average score difference of 3.91, whereas the KKf of the learning group with FSLMS was higher than the group with TFSLMS. However, the standard deviation score of the learning group with FSLMS was lower by 3.97 than the math learning group with TFSLMS; and

2. The highest score in the math learning group with FSLMS was 2 points higher, but the lowest score was the same as that of the TFSLMS group.

Based on the data, the KKf achievement of prospective elementary school student teachers in the FSLMS group is better than that of the TFSLMS group. In addition, inferential tests were conducted for differences in creative thinking skills between the FSLMS and TFSLMS groups. Based on the normality test, it was found that the results of KKf achievement data of prospective elementary school student teachers in the mathematics learning groups with FSLMS and TFSLMS are not normally distributed. On that basis, the difference test was conducted using the Mann-Whitney test using $\alpha=0,05$. The test results are shown in Table 5 .

Table 5: Test differences in KKf achievement of prospective elementary school student teachers

\begin{tabular}{|c|c|}
\hline & KKf \\
\hline Mann-Whitney U & 2853,500 \\
\hline Wilcoxon W & 6681,500 \\
\hline Z & $-3,188$ \\
\hline Asymp. Sig. (2-tailed) & 0,001 \\
\hline
\end{tabular}

\subsection{Discussion}

Autonomy is one aspect of psychological well-being that can affect student learning outcomes (Winch, 2002). By having good autonomy, students will have high levels of independence in learning as well. People who are positive in terms of psychological well-being (PWB) are happy, healthy, productive, and have satisfying interpersonal relationships (Ryff, 2013). In a learning situation that is affected by the Covid-19 pandemic as it is today, learning is mostly directed at blended learning or learning that combines synchronous and asynchronous techniques. These are highly dependent on the independence of students' learning because the teacher only facilitates and provides motivation from a distance. In this study, LMS-assisted mathematics learning shows that the students in the class with mathematics learning with LMS-assisted science phenomena descriptively have a higher level of autonomy. This is indicated by a higher average score. The percentage of students who have higher levels of autonomy is greater than in the class without scientific phenomena. This indicates that computers can help students learn mathematics and problem-solving (Bell, 2010; Hatfield \& Kieren, 1972; Robitaille et al., 2020).

However, inferentially the results show that there is no significant difference. In this research, LMS is needed as a learning tool during a pandemic to manage the learning (Robitaille et al., 2020). Learning is strongly influenced by the subject 
material, the teacher, the novelty effect, and the learning content. Although the LMS offers various teaching materials such as audio-video, audio, and presentations, independent learning will determine whether students can choose one, or study all of the teaching materials presented, or even not choose any of the teaching materials delivered. Students who study independently will be able to determine the learning resources they want to learn or even study other teaching materials as enrichment. Meanwhile, students with low autonomy will depend on the instruction and supervision of the teacher or instructor.

Creative thinking skills is one of the most important skills of this century, and are the highest-level skills in Bloom's taxonomy (Krathwohl, 2010). Therefore, these skills play a very important role in individual success. In this research, learning mathematics with LMS-assisted science phenomena has shown to have an impact on students' creative thinking skills as shown in Table 4.1. Descriptively, the average creative thinking skills of students who study mathematics with LMSassisted science phenomena are almost twice those of the comparison classes' average. This is also reinforced by the results of the inferential test which shows that there is a significant difference in the alpha of $5 \%$.

Furthermore, learning with LMS-assisted science phenomena applied in this research provides opportunities for students to explore the surrounding environment through didactic phenomena that appear in students' daily lives. In this learning, students conduct experiments that can provide opportunities for them to develop their imagination, and ways and methods of completing and reporting assigned experiments. In group experiments, students can also share ideas in solving problems. This is in line with previous preliminary research on LMS which also has a positive influence on mathematical creative thinking skills (Widodo, 2017). This is supported by research by Garrison and Anderson (2003), who found that technology is a learning tool used in formal education practices to disseminate, illustrate, communicate, or support students and teachers in activities designed specifically to sustain learning (Gunawan et al., 2019). This indicates that learning using multimedia electronics is more significant than conventional learning (Munir, 2010).

The analysis was continued to determine whether there is a relationship between autonomy and creative thinking skills. Based on the correlation coefficient, a score of 0.24 was obtained. Therefore, it can be concluded that there is a low relationship between the two variables. This is not according to the views of Winch (2002) who stated that autonomy is in line with critical thinking skills. Therefore, further research needs to be done on other aspects of psychological well-being related to creative thinking skills as part of 21st century skills.

\section{Conclusion}

Based on the analysis and discussion of these results, it can be concluded that the autonomy of prospective elementary school teachers in learning mathematics with LMS-assisted science phenomena is no different from learning mathematics without LMS-assisted science phenomena. Both of these lessons produce autonomy for students because they provide equal opportunities to study a 
variety of teaching materials. The creative thinking ability of students in the experimental classes is better than that of students in the control classes because students in the experimental classes are more likely to improve their creative thinking skills and are allowed to explore the surrounding environment through didactic phenomena that appear in students' daily lives. This research has shown that what needs to be followed up in further research is how elementary school candidate teachers can explore additional teaching materials independently that are not available in LMS. Therefore, to improve their ability of autonomy and creative thinking, teachers need to adopt innovative learning such as mastering LMS as learning management in selecting materials and implementing the teaching and learning process effectively. The results reported here should be interpreted in the light of these considerations.

\section{References}

Afifah, N. M. (2019). Keterampilan abad 21 dalam pembelajaran matematika berbasis proyek [21 ${ }^{\text {st }}$ century skills in project-based mathematics learning]. UIN Sunan Ampel Surabaya.

Aisah, L. S. (2015). Pembelajaran Matematika Berbasis Fenomena Didaktis Melalui Pendekatan Saintifik Untuk Meningkatkan Kemampuan Koneksi Matematis Dan Self-Esteem Siswa SMP [Didactic Phenomenon-Based Mathematics Learning Through a Scientific Approach to Improve Mathematical Connection Ability and Self-Esteem of Junior High School Students]. Universitas Pendidikan Indonesia.

Ashcrafts, M. (2002). Math anxiety: Personal, educational, and cognitive consequences. Current Directions in Psychological Science, 11(5). https://doi.org/10.1111/14678721.00196

Ayers, T., Davis, G., Dubinsky, E., \& Lewin, P. (1988). Computer experiences in learning composition of functions. Journal for Research in Mathematics Education, 19, 246-259.

Bealty, B., \& Ulasewicz, C. (2006). Online teaching and learning in transition: Faculty perspectives on moving from blackboard to the moodle learning management system. Journal Techtrends, 50(4), 36-45.

Becker, K., \& Park, K. (2011). Effects of integrative approaches among science, technology, engineering, and mathematics ( STEM ) subjects on students' learning: A preliminary meta-analysis. Journal of STEM Education, 12(5), 23-38. https://doi.org/10.1037/a0019454

Bell, S. (2010). Project-based learning for the 21st century skills. http://doi.org/10.1080/00098650903505415

Blyth, B., \& Labovic, A. (2009). Using Maple to implement eLearning integrated with computer-aided assessment. International Journal of Mathematical Education in $\begin{array}{llll}\text { Science } \quad \text { and } & \text { Technology, }\end{array}$ https://doi.org/10.1080/00207390903226856

Brendefur, J., \& Frykholm, J. (2000). Promoting mathematical communication in the classroom: Two pre-service teachers' conceptions and practices. Journal for Research in Mathematics Education, 3(125). https://doi.org/10.1023/A:1009947032694

Chiam, L. C., Hong, H., Ning, F. H., \& Tay, W.Y. (2014). Creative and Critical Thinking in Singapore Schools. Office of Education Research, National Institute of Education, Nanyang Technological University.

Dye, A., \& Fagerberg, T. (2004). Exploring online service in a mobile environment. Technical Working Paper.

Effendi, L. A. (2012). Pembelajaran Matematika Dengan Metode Penemuan Terbimbing Untuk Meningkatkan Kemampuan Representasi Dan Pemecahan Masalah 
Matematis Siswa SMP [Learning Mathematics with Guided Discovery Methods to Improve Representation and Mathematical Problem Solving Skills for Junior High School Students]. Jurnal Penelitian Pendidikan, LPPM UPI, 13(2).

Faturohman, D. R. (2015). Pembelajaran Matematika Berbasis Fenomena Didaktis Melalui Pendekatan Scientific untuk Meningkatkan Kemampuan Berpikir Kritis dan Kemandirian Belajar Siswa SMP [Didactic Phenomenon-Based Mathematics Learning Through a Scientific Approach to Improve Critical Thinking Ability and Independent Learning of Junior High School Students]. Universitas Pendidikan Indonesia.

Fauzi, M. R., \& Priatna, N. (2019). Analysis of student's mathematical connection and communication in algebra: the exponential equations. Journal of Physics: Conference Series, 1211 012065. https://doi.org/10.1088/1742-6596/1211/1/012065

Fauzi, A. (2015). The enhancement of student's Mathematical connection ability and selfregulation learning with metacognitive learning approach in junior high school. In Proceedings of the International Conference on Research and Education in Mathematics (ICREM7). https:/ / doi.org/10.1109/ICREM.2015.7357048

Fraenkel, J. R., \& N. E. W. (2012). How to design and evaluate research in education (8th ed.). McGraw-Hill Higher Education.

Freudenthal, H. (2002). Phenomenology, didactical mathematical, O F. Springer Netherlands.

Fuchs, L. S., Fuchs, D., Prentice, K., Hamlett, C. L., Finelli, R., \& Courey, S. J. (2004). Enhancing mathematical problem solving among third-grade students with schema-based instruction. Journal of Educational Psychology, 96(4), 635-647. https://doi.org/https://doi.org/10.1037/0022-0663.96.4.635

Giarti, S. dan Astuti, S. (2016). Implementasi TQM Melalui Pelatihan Model in House Training untuk Meningkatkan Kompetensi Pedagogik Guru SD [Implementation of TQM through Model in House Training to Improve Pedagogic Competence of Elementary School Teachers]. Scholaria Jurnal Pendidikan Dan Kebudayaan, 6(12). https://doi.org/10.24246/j.scholaria.2016.v6.i2.p80-91

Göksün, D. O., \& Gürsoy, G. (2019). Comparing success and engagement in gamified learning experiences via Kahoot and Quizizz. Journal Computers \& Education, 135, 15-29. https://doi.org/10.1016/j.compedu.2019.02.015

Gunawan, G., Sahidu, H., Susilawati, S., Harjono, A., \& Herayanti, L. (2019). Learning management system with Moodle to enhance creativity of candidate physics teacher. Journal of Physics: Conference Series, 1417(1), 0-6. https://doi.org/10.1088/1742-6596/1417/1/012078

Hamadneh, I. M., \& Al-Masaeed, A. (2015). Math teachers' attitudes towards photo math application in solving mathematical problem using mobile camera. Educational Research and Reviews, 10(14), 1930-1936. https://doi.org/10.5897/ERR2015.2181

Hatfield, L. L., \& Kieren, T. E. (1972). Computer-assisted problem solving in school mathematics. Journal for Research in Mathematics Education, 3(2). https://doi.org/10.2307/748668

Hidayat, A. (2015). Perbandingan Kemampuan Berpikir Kreatif Matematis Serta Self-Efficacy Antara Siswa MTs yang Memperoleh Pembelajaran Berbasis Fenomena Didaktis dan Berbasis Kurikulum 2013 Melalui Pendekatan Invesitigasi [Comparison of Mathematical Creative Thinking Ability and Self-Efficacy Between MTs Students Who Received Didactic Phenomenon-Based Learning and 2013 Curriculum-Based Through Investigation Approach]. Universitas Pendiidkan Indonesia.

Huebner, S. E., \& McCullough, G. (2010). Correlates of school satisfaction among adolescents. Journal of Educational Research, 93(5). https://doi.org/10.1080/00220670009598725

Kaput, J., Hegedus, S., \& Lesh, R. (2019). Foundations for the future in mathematics education. Routledge. 
Kelley, T. R., Knowles, J. G., Abell, S., Lederman, N., Bandura, A., Bandura, A., Williams, D. (2016). A conceptual framework for integrated STEM education. International Journal of STEM Education. https://doi.org/10.1186/s40594-016-0046-z

Keyes, C. L. M., \& Ryff, C. D. (1999). Psychological well-being in midlife. In S. L. Willis \& J. D. Reid (Eds.), Life in the middle: Psychological and social development in middle age. Academic Press. https://doi.org/10.1016/B978-012757230-7/50028-6

Kim, Y., \& Park, N. (2012). The effect of STEAM education on elementary school student's creativity improvement. Communications in Computer and Information Science, 339 CCIS, 115-121. https://doi.org/10.1007/978-3-642-35264-5_16

Kline, M. (1973). Why JoHnny can't add: The failure of the new math. Vintage Books.

Kösa, T., \& Karakuş, F. (2010). Using dynamic geometry software Cabri 3D for teaching analytic geometry. Procedia - Social and Behavioral Sciences, 2(2), 1385-1389. https://doi.org/10.1016/j.sbspro.2010.03.204

Kramarski, B., \& Mevarech, Z. R. (2003). Enhancing mathematical reasoning in the Cclassroom: The effects of cooperative learning and metacognitive training. American Educational Research Journal, 40(1), 281-310. https:// doi.org/10.3102/00028312040001281

Lestari, S. A. P. (2019). Mathematical reasoning ability in relations and function using the problem solving approach. Journal of Physics: Conference Series, 1188(012065). https://doi.org/10.1088/1742-6596/1188/1/012065

Maslukha, M., Lukito, A., \& Ekawati, R. (2018). Refractive thinking profile in solving mathematical problem reviewed from students math capability. Journal of Physics: Conference Series, 947(012022).

McGill, T. J., \& Klobas, J. (2009). A task-technology fit view of learning management system impact. Journal Computers \& Education, 52(2), 496-508. https:// doi.org/10.1016/j.compedu.2008.10.002

Merzbach, U. C., \& Boyer, C. B. (2011). A history of mathematics. John Wiley \& Sons. https://doi.org/10.2307/3620228

Muhajir, S. (2018). Penerapan project oriented problem based learning dengan reading infusion. Untuk melatihkan keterampilan abad Ke 21 Mahasiswa. Universitas Pendidikan Indonesia.

Munir. (2010). Penggunaan learning management system (LMS). Di Perguruan Tinggi: Studi Kasus Di Universitas Pendidikan Indonesia [Use of learning management system (LMS). In Higher Education: A Case Study at the Indonesian University of Education]. Cakrawala Pendidikan, 29(1), 109-119. https://doi.org/10.21831/cp.v1i1.222

Muqodas, I. (2019). Konseling Kesejahteraan untuk Meningkatkan Kesejahteraan Psikologis Mahasiswa [Welfare Counseling to Improve Student Psychological Well-being]. Universitas Pendidikan Indonesia.

Mushlihuddin, R., \& Nurafifah, I. (2018). The effectiveness of problem-based learning on students' problem solving ability in vector analysis course. Journal of Physics: Conference Series, 948(012028). https:// doi.org/10.1088/1742-6596/948/1/012028

Nabilah, N. G. S., Suhendra, S., \& Yulianti, K. (2019). The efforts of improving mathematical connection ability of senior high school student with 7e learning cycle model. Journal of Physics: Conference Series, 1157(042096).

NCTM. (2000a). Executive summary principles and standards for school mathematics. https://www.nctm.org/uploadedFiles/Standards_and_Positions/PSSM_Executi veSummary.pdf

NCTM. (2000b). Principles and standards for school mathematics overview. Journal of Equine Veterinary Science.

P21. (2011). 21st century skill map. http://www.21.org 
Penglase, M., \& Arnold, S. (1996). The graphics calculator in mathematics education: A critical review of recent research. Mathematics Educational Research Journal, 8, 58-90. https://doi.org/10.1007/BF03355481

Rees, G., Goswani, H., \& Bradshaw, J. (2010). Developing an index of children's subjective well being in England. The Children's Society.

Robitaille, D. F., Sherrill, J. M., \& Kaufman, D. M. (2020). The effect of computer utilization on the achievement and attitudes of ninth-grade mathematics students. Journal for Research in Mathematics Education, 8(1), 26-32. https://doi.org/10.5951/jresematheduc.8.1.0026

Rosyid, A. (2015). Pembelajaran Matematika Berbasis Fenomena Didaktis Melalui Pendekatan Saintifik untuk Meningkatkan Kemampuan Komunikasi Matematis dan Self-Confindence Siswa SMP [Didactic Phenomenon-Based Mathematics Learning Through a Scientific Approach to Improve Mathematical Communication Skills and SelfConfindence of Junior High School Students]. Universitas Pendidikan Indonesia.

Ryff, C. D. (2013). Psychological well-being revisited: Advances in the science and practice of eudaimonia. Psychotherapy and Psychosomatics, 83(1), 10-28. https:// doi.org/10.1159/000353263

Salehudin, N. N., Hassan, N. H., \& Hamid, N. A. A. (2015). Matematik dan Kemahiran Abad Ke-21: Perspektif Pelajar [21st Century Mathematics and Skills: Student Perspectives]. Jurnal Pendidikan Matematik., 3(1), 24-36.

Savedra, A. R \& Ofter, V. D. (2012). Learning 21st century skills requires 21st century teaching. The Phi Delta Kappan, 94(2), 8-13. https://doi.org/10.1177/003172171209400203

Siregar, N.R. (2017). Persepsi siswa pada pelajaran matematika: studi pendahuluan pada siswa yang menyenangi game [Students' perceptions of mathematics: a preliminary study on game-loving students]. Prosiding Temu Ilmiah Nasional X Ikatan Psikologi Perkembangan Indonesia, Vol 1.

Staker, H., \& Horn, M. B. (2012). Classifying K-12 Blended Learning.

Stern, S. (2007). Factors that impact the health and psychological well-being of older adults shortly following institutionalization. Case Western Reserve University.

Suryadi, D. (2005). Penggunaan Pendekatan Pembelajaran Tidak Langsung serta Pendekatan Gabungan Langsung dan Tidak Langsung dalam Rangka Meningkatkan Kemampuan Berpikir Matematik Tingkat Tinggi Siswa SLTP [The Use of Indirect Learning Approaches and Combined Direct and Indirect Approaches in Order to Improve High-Level Mathematical Thinking Skills for Junior High School Students]. Universitas Pendidikan Indonesia.

Tobin, S.S., \& Neugarten, B. L. (1961). Life satisfaction and social interaction in the aging. Journal of Gerontology, 16, 344-346. https://doi.org/10.1093/geronj/16.4.344

Torrance, E. P. (1966). The Torrance tests of creative thinking-norms-technical manual research edition -Verbal tests, Forms A and B - Figural tests, Forms A and B. Personnel Press.

Torrance, E. P. (1974). The Torrance tests of creative thinking-norms-technical manual research edition - Verbal tests, Forms A and B - Figural tests, Forms A and B. Personnel Press.

Turmudi, T. (2014). Pengembangan pembelajaran matematika berbasis fenomena didaktis [Development of didactic phenomenon-based mathematics learning]. Universitas Pendidikan Indonesia

Turmudi, T., Hidayat, A. S., \& Sispiati, R. (2017). Mathematics instruction based on science using didactical phenomenology approach in junior secondary school in Indonesia. Intech Open. http://dx.doi.org/10.5772/intechopen.68437

Watson, W. R., \& Watson, S. L. (2007). An argument for clarity: What are learning management systems. What are they not, and what should they become? TechTrends, $51(2)$ $28-34$. 
http://cardinalscholar.bsu.edu/handle/123456789/194513

Weaver, D., Spratt, C., \& Nair, C. S. (2008). Academic and student use of a learning management system: Implications for quality. Australian Journal of Educational Technology, 24(1). https://doi.org/10.14742/ajet.1228

Widodo. (2016a). Profesor Ini Ungkap Mengapa Matematika Dianggap Sulit [This Professor Reveals Why Mathematics Is Considered Difficult]. Suara.com: Edisi Rabu. Suara.Com.

Widodo, A. (2016b). Teacher pedagogical content knowledge (PCK) and students reasoning and wellbeing. Journal of Physics: Conference Series, 812. http://doi.org/10.1088/1742-6596/812/1/012119

Widodo, S. (2017). Implementing Google Apps for education as learning management system in math education. Journal of Physics: Conference Series, 895(1). https:// doi.org/10.1088/1742-6596/895/1/012053

Winch, C. (2002). Strong autonomy and education. Educational Theory, 52(1).

Xiao, X., Xu, H., \& Xu, S. (2015). Using IBM SPSS modeler to improve undergraduate mathematical modelling competence. Computer Applications in Engineering Education, 23, 603-609. https://doi.org/10.1002/cae.21632 